\title{
Why sustainable population growth is a key to climate change and public health equity
}

\author{
Peter Howat and Melissa Stoneham
}

\section{Background}

Australia's population will reach 42 million by 2050, six million more than the Federal Government's 2010 Intergenerational Report's projection, if migration, fertility and life expectancy continue at today's pace. ${ }^{1}$ Recent accelerated population growth in Australia is mainly due to policy decisions taken by the Federal Government. While these actions bring some short-term economic gains, there is concern that they are not in the public interest, do not promote a sustainable future and represent mainly narrow, vested business interests. ${ }^{2}$

There are concerns about the long-term economic costs of such rapid population growth. ${ }^{3}$ The Secretary to the Treasury, in a March 2010 address to the Conference on the Economics of Infrastructure, questioned how well the Australian infrastructure will cope if this large influx of people continues. ${ }^{4}$ It is likely that Australia will require substantially higher taxes to pay for infrastructure needed to provide health, energy, transport and food for such a rapidly growing population. ${ }^{3}$

Other authorities warn about the public health and environmental effects of a larger Australian population. ${ }^{3,5}$ Recent polls recorded more than $70 \%$ of Australians were concerned about rapid population growth, particularly as it is likely to be associated with declining living standards, increased traffic congestion, power blackouts, water restrictions, unaffordable housing, environmental destruction, urban crowding, reduced service delivery and falling health status. ${ }^{6}$

Warnings about environmental pollution given more than 40 years ago by Rachel Carson ${ }^{7}$ in Silent Spring, followed by a host of writings in the 1970s about overpopulation by concerned scientists, produced little political action. ${ }^{8}$ Public advocacy and substantial media attention on the population issue in 2010 undoubtedly influenced the Federal Government to re-examine its stance.

Population policy in Australia is an emerging area. Only in 2010, did the Gillard Government launch its Sustainable Population Policy platforms. ${ }^{9}$ But, is Australia ready to make a policy on population? ${ }^{10,11}$ Has there been enough evidence, or open debate, about whether we can live sustainably if the population expands, or it would be better to try and slow population growth to maintain health and wellbeing?

\begin{abstract}
Footnote:
Some people cloud the issue of population sustainability by claiming that it is a deliberate ploy by proponents to reduce the entry of legitimate refugees. We suggest that the 'refugee issue' should be dealt with separately and not as a part of the debate on 'sustainable population'. In recent years, refugees have comprised less than $5 \%$ of immigrants to Australia and their numbers have minimal impact on the total population size. ${ }^{2}$
\end{abstract}

\section{Abstract:}

Australia's population could reach 42 million by 2050. This rapid population growth, if unabated, will have significant social, public health and environmental implications. On the one hand, it is a major driver of climate change and environmental degradation; on the other it is likely to be a major contributor to growing social and health issues including a decline in quality of life for many residents. Disadvantaged and vulnerable groups will be most affected.

The environmental, social and health-related issues include: pressure on the limited arable land in Australia; increased volumes of industrial and domestic waste; inadequate essential services; traffic congestion; lack of affordable housing; declining mental health; increased obesity problems; and inadequate aged care services. Many of these factors are related to the aggravation of climate change and health inequities.

It is critical that the Australian Government develops a sustainable population plan with stabilisation of population growth as an option. The plan needs to ensure adequate hospitals and healthcare services, education facilities, road infrastructure, sustainable transport options, water quality and quantity, utilities and other amenities that are already severely overburdened in Australian cities. There is a need for a guarantee that affordable housing will be available and priority be given to training young people and Indigenous people for employment.

This paper presents evidence to support the need for the stabilisation of population growth as one of the most significant measures to control climate change as well as to improve public health equity.

Key words: population policy; climate change; public health equity; sustainable growth

Health Promotion Journal of Australia 2011;22: S34-S38

\section{So what?}

Evidence in support of stabilising population growth will help inform the development of appropriate policies that should help Australia meet its climate change targets, and ultimately benefit vulnerable members of our community. 
This paper aims to contribute to the evidence base on which these policy decisions can be further debated. It is not a comprehensive document that outlines all pros and cons of population growth in Australia, but rather briefly highlights some of the key factors that should be considered when developing policy. Issues that support the need for a sustainable population policy and why this is relevant to climate change and public health equity are presented.

\section{Australia's population and its links to climate change}

Linking population dynamics with climate change is a sensitive issue. However, the contribution of population growth to increased greenhouse emissions needs urgent attention. Australia's projected population increase will mainly come from net migration. ${ }^{1}$ The majority of migrants come to Australia from countries where individual ecological footprints are small and per capita emissions are one-third or less than those of Australia. Yet upon arrival, the migrants adopt the Australian lifestyle, increase consumption patterns and develop a footprint similar to other Australian residents. A principle cause of climate change is high consumption by people in developed countries. ${ }^{12}$

There is general agreement that human industrial activity has released large quantities of greenhouse gases, about 900 billion tonnes of carbon dioxide $\left(\mathrm{CO}_{2}\right)$, half of which remain in the atmosphere. About $80 \%$ of $\mathrm{CO}_{2}$ emission is caused by industrialisation and the remaining by land use such as deforestation. ${ }^{12}$ There is strong evidence that the burning of fossil fuels since the beginning of the industrial revolution has already caused a $0.75^{\circ} \mathrm{C}$ rise in global temperatures and a 22 centimetre rise in sea level during the $20^{\text {th }}$ century. ${ }^{12}$

\section{Climate change and global warming - the Australian context}

International concerns about climate change and global warming have led to much publicity and political discussion but with few tangible outcomes. Unfortunately, it appears that population dynamics have not been integrated systematically into climate change science. ${ }^{12,13}$ Regardless of whether global warming is caused by humans or part of a natural cycle, evidence of the effects of climate change and global warming is mounting, and in line with the precautionary principle, should not be ignored in any political arena.

The Australian Government has stated an unconditional commitment to reduce greenhouse gas emissions by $5 \%$ on year 2000 levels by 2020. ${ }^{14}$ However, in the absence of abatement measures, Treasuryled modelling indicates that Australia's emissions will grow from 553 million tonnes in 2000 to 774 million tonnes in 2020. Birrell and Healy ${ }^{1}$ disaggregated the Treasury modelling in order to estimate the contribution of population expansion to this growth and found that $83 \%$ of the forecast increase in greenhouse emissions to 2020 will be attributable to population growth.

In comparison with Organization for Economic Cooperation and Development (OECD) countries, Australia has a poor environmental record. It produces almost $2 \%$ of the world's greenhouse gases (GHG). Per capita, Australians produce 26 tonnes of $\mathrm{CO}_{2}$ each year, the highest in the developed world. ${ }^{15}$ By contrast, in Britain and most of Europe; the average is about 11 tonnes, in China 4 tonnes, and in India 2 tonnes. Recognising that GHG emissions have been growing more quickly than was anticipated in the Intergovernmental Panel on Climate Change's Fourth Assessment Report, ${ }^{16}$ the Garnaut Report argued that Australian emissions reductions of 70 to $90 \%$ on 2000 levels are needed by 2050 under global emission stabilisation scenarios of 550 ppm and 450 ppm of $\mathrm{CO}_{2}$ respectively. ${ }^{17}$

Many experts consider curbing population growth is the single most important strategy to reduce global warming. ${ }^{2,5}$ Recent calculations for example, confirm that the most effective way to control $\mathrm{CO}_{2}$ emissions is related to reproductive choices by reducing birth rates..$^{18}$

This paper discusses evidence of environmental, social and health related issues that support the urgent need for a plan for the stabilisation of Australia's population growth.

\section{Limited arable land}

Proponents of population growth perpetuate the myth that Australia has enormous tracts of land that can accommodate a large, sustainable population. However, Australia is largely arid, with nutrientpoor soils and inconsistent rainfall. ${ }^{8}$

More than half the continent is already grazed, and much of its soils are rapidly degrading, eroding, or becoming saline. Only about $6 \%$ of Australian land is arable, compared with $20 \%$ in the US. Of this $6 \%$, salinity is likely to severely damage an estimated 17 million hectares within 50 years. ${ }^{2,8,19}$

The Intergovernmental Panel on Climate Change considered biodiversity to be the sector most at risk from the effects of rapid climate change. ${ }^{20}$ Land clearing has affected biodiversity, with a clear example being the Murray Darling Basin. The removal of an estimated 12-15 billion trees in this Basin has significantly influenced regional climate such as temperature and rainfall patterns. ${ }^{21}$ This, in turn, has exacerbated prolonged droughts, with corresponding negative impacts on birds. ${ }^{22}$ With land clearing, inconsistent rainfall and a shortage of arable land, rapid population growth will increase the demand for food. Australia is under pressure to make its the productive land already in use even more productive. Simultaneously, urbanisation practices are building on fertile land that was once market gardens for cities, forcing food production areas to be located greater distances from cities and increasing food miles.

Some claim a solution to the population problems of Australia's major cities is to relocate people to rural and regional Australia. The reality however, is that water shortages make this an unviable option. For example, the environmental decline in the Murray-Darling Basin is largely due to insufficient environmental water over decades. ${ }^{23}$ This now threatens many economic, biological and social processes of the region making it clear that the Murray- Darling region is so stressed it is unable to absorb population from rapidly growing capital cities.

\section{Waste production}

\section{Industrial waste and greenhouse gas emissions}

The Earth is committed to significant warming as a consequence of increases in greenhouse gas (GHG) emissions. ${ }^{24} \mathrm{~A}$ primary task is of mitigation, including significantly reducing emissions of carbon dioxide from the combustion of fossil fuels at the global scale. ${ }^{25}$ Australia has many gains to make in this area. The identification 
of alternative sources of energy to fossil fuels is a key strategy to reduce $\mathrm{GHG}$ emissions. ${ }^{26}$

Cutting GHG emissions is a significant challenge in Australia for a number of reasons, including the nation's economy being heavily dependent on the mining industry, ${ }^{27,28}$ which directly and indirectly leads to large GHG emissions, and our very high per capita levels of energy consumption. When combined with the rapid population growth, there is a need for multi-scaled responses, both in mitigation and adaptation.

\section{Domestic waste and greenhouse gas emissions}

A consequence of Australia's fast-growing, materially intensive economy is the production of large quantities of waste. Economic growth contributes to growth in waste generation per person. ${ }^{29}$ By far the largest contributor to waste-sector GHG emissions is the decomposition of organic waste in landfill including paper and cardboard, food and garden organics, and wood and timber. As the organic carbon of such materials decomposes it produces a waste gas which comprises approximately 50\% methane $\left(\mathrm{CH}_{4}\right)$ and $50 \% \mathrm{CO}_{2}$.

Australians have a large ecological footprint, demonstrated with the following example. The Australia Institute's Wasteful Consumption in Australia report ${ }^{30}$ revealed that in 2004 , Australians spent $\$ 10.5$ billion on goods and services that they never or hardly ever used. Food consumption was the largest waste category: Australians threw away \$5.3 billion worth of all forms of food in 2004 .

The average amount of waste produced by every Australian almost doubled from 1,200 kilograms in 1996-97 to 2,100 kilograms in 2009. ${ }^{31}$ Even with austere resource-use policies, Australians are likely to maintain this high rate of consumption, made worse by high population growth. ${ }^{2}$

The health effects of waste include the gases emitted from landfill sites, principally $\mathrm{CH}_{4}$ and $\mathrm{CO}_{2}$. Other gases, such as hydrogen sulphide $\left(\mathrm{H}_{2} \mathrm{~S}\right)$ and mercury vapour are also emitted at low concentrations, as are a mixture of volatile organic compounds (VOCs). Other health concerns associated with increased waste production include microbial pathogens from composting and landfill processes, dust and the production of particulate matter through incineration and composting processes and from road traffic involved in all waste management options. All these health effects will be increased substantially with a rising population.

\section{Services}

In most Australian cities, the infrastructure cannot cope with the populations it serves. This is true of schools and colleges, roads and transport systems, hospitals and health care, housing supply, water, power and gas utilities and other amenities. Current population growth rates push the demands for these services well beyond the capacity for adequate funding. The result is declining quality and availability and disadvantaged groups in the community are most affected. ${ }^{3}$

The problem lies in the provision of infrastructure to keep up with increasing population growth at a far greater rate than the growth in GDP or tax revenue. Infrastructure such as roads and buildings are estimated to last about 50 years, so about $2 \%$ of it requires replacing each year when the population is stable. However, if the population is growing by $2 \%$ a year (as it was over the past few years) an extra $2 \%$ of (new) infrastructure will be needed, doubling the cost. ${ }^{32}$ While tax revenues increase only around $2 \%$ in response to a $2 \%$ population growth, the expenditure needed to maintain infrastructure levels increases $100 \%$. This is more money than any government can extract from the taxpayers, and provides one explanation of why infrastructure is inadequate in areas where population is growing at a fast rate. In relation to health personnel, it is predicted that if population grows at 2\% a year, Australia will need to recruit at least $50 \%$ more trained health professionals each year to maintain service levels per capita. Far from being the solution, skilled migration exacerbates the need for Australian graduates. ${ }^{32}$

\section{Traffic congestion}

Transport is Australia's third-largest and second-fastest-growing source of GHG emissions. The road transport sector makes up 88\% of total transport emissions. The projected $64 \%$ emissions increase from 1990 to 2020 will be exacerbated by rapid population growth. ${ }^{33}$ A Government report ${ }^{30}$ estimates an increase of passengers on public transport by $18 \%$, road freight by $32 \%$ and traffic congestion by up to $69 \%$ in Perth. The report estimated the avoidable cost of this congestion Australia-wide was $\$ 9.4$ billion in 2005 , but could more than double to $\$ 20.4$ billion in $2020 .{ }^{34}$

Passenger vehicles are the largest source of $\mathrm{GHG}$ emissions from road transport and accounted for around 61\% in 2007.35 On average, for every litre of petrol used in a motor vehicle, 2.3 kilograms of $\mathrm{CO}_{2}$ is released from the exhaust. ${ }^{35}$

Given that most travel in Australia is by car, reducing vehicle kilometres by shortening trip lengths and increasing trip chaining will lower emissions. Increasing public transport options including more regular and low-cost services would help alleviate GHG emissions.

A specific health issue related to traffic congestion is asthma. The main issues associated with respiratory diseases are photochemical smog in summer and particle haze during winter. A major source of pollution is motor vehicles. Particulate air pollution, mainly from vehicle exhaust, along with ozone, aggravates asthma and increases coughs and bronchitis. ${ }^{36,37}$

\section{Housing affordability}

Between 2000 and 2008, Australian house prices increased by 50\% in real terms. Rental prices also increased substantially during this time, making housing affordability difficult for an increasing proportion of Australians, especially those with low incomes or living on welfare assistance. ${ }^{38}$ Escalating housing prices are purportedly driven largely by population growth. The National Housing Supply Council ${ }^{39}$ estimated a shortfall in supply of 178,400 dwellings. The Council suggests this deficit will rise to 640,000 dwellings by 2029 and is likely to further inflate the price of homes, as well as increase the potential for over-crowding especially amongst low income groups. The rapid population growth is also placing substantial pressure on available public housing in Australian cities. Low income groups are again most affected. For example, by late 2010 there were almost 55,000 West Australians on the waiting list for public housing, including 8,400 on the priority list. ${ }^{40}$ 
The likely impact of unsustainable population growth is that vulnerable groups within communities will have less opportunity to escape deprived neighbourhoods where social and environmental characteristics present significant risks to health. These include substandard housing, higher crime rates, poorer air quality, and a lack of green spaces as well as increased risks of traffic injury. ${ }^{41}$ Poor housing conditions pose serious health threats such as respiratory problems in children and the elderly through inadequate heating and insulation. ${ }^{42}$ In addition, low levels of social integration and loneliness which are related to increased risk of depression, cognitive decline and dementia, are more common in such neighbourhoods. ${ }^{43}$

\section{Mental health}

Rapid growth, increasing urbanisation including crowding, and "the pace of modern life" are touted as significant contributors to stress and depression ${ }^{44}$ and the risk of developing schizophrenia. ${ }^{45}$ A growing research base shows that contact with the natural world provides social, health and psychological benefits. However, these benefits are becoming harder to secure with the shift to more pressured patterns of city and urbanised living including high density housing. ${ }^{46}$ This is of particular concern for the health status of vulnerable populations and in particular children and people with low-incomes. ${ }^{47}$

\section{Aged care services}

An estimated $25 \%$ of Australians will be aged 65 years and over by 2056. ${ }^{3}$ One of the claimed benefits of the current rapid population growth is that Australia will be better placed to cope with the ageing population as it will keep Australia'younger.' However, demographers agree that even the high levels of net migration envisaged in the Third Intergenerational Report ${ }^{48}$ will make little difference. If net migration (immigrants minus emigrants) is reduced to zero Australia's population would grow from 22.3 million (in May 2010) to only 23.1 million in the year 2054, but $27 \%$ of our population would be aged 65 years or over. ${ }^{38}$ If we kept net migration at around 180,000 Australia's population would rise to more than 36 million, and $22 \%$ of people would be aged over 65 years. Even with the lower proportion of people over 65 in this scenario, the total number of elderly people requiring aged care services and treatment for chronic diseases would grow substantially. Recent reports indicate the health systems throughout Australia are already struggling to cope with the current population of 22.3 million people ${ }^{49}$ and that investment in addressing the problem is falling well behind what is needed ${ }^{50,3}$ Rapid population growth adds to this pressure on health services infrastructure.

\section{Workforce requirements}

The projected need for more people in the workforce to replace those retiring, and to meet projected employment growth associated with rapid population increases, is one of the key arguments for maintaining a high population growth for Australia. However, a significant reduction in the projected workforce shortfall could be achieved by measures that could also increase social inclusion by breaking down barriers to workforce participation. There is a great opportunity to increase participation rates among Aboriginal Australians, women, some migrant groups (e.g. refugees) and people with a disability, as well as older and younger workers. ${ }^{51}$ There is a further need for Federal and State Government policies to provide increased education and training opportunities to build the skill level of the Australian workforce. Increased focus on this would comply with one of the six policy objectives to address the social determinants of health espoused by the Marmot Report. ${ }^{41}$

\section{Implications for policy}

There is strong sensitivity in some public health quarters about policy related to population. Rational debate and publication of articles about sustainable population is often stifled by this perception. On the other hand, there is an abundance of literature that promotes rapid population growth, mainly presented by economists and business growth advocates with an emphasis on short-term economic gain. We believe it is important for public health professionals to become more immersed in the issue as it relates to public health and equity so more appropriate policies are developed for the long-term benefits of all Australians, and particularly to improve the lot of our most disadvantaged members.

\section{Climate change and public health equity}

In a recent article, Sir Michael Marmot, a leader in social determinants of health research, stresses the need to reduce health inequalities through three fundamental drivers: economics, social policies and governance. ${ }^{52}$ Marmot and his colleagues supported sustainable population policies, with their assertion that tackling social inequalities in health and "tackling climate change must be addressed together".52 Marmot has suggested six policy objectives to reduce health inequalities, with one being particularly relevant to sustainable population growth:"Creating and developing healthy and sustainable places and communities.".1 A healthy and sustainable community is one where everyone has access to good quality air, food, water, housing, employment, sporting, recreational, cultural facilities and green space. It has been shown that the provision of well-designed green space can improve mental and physical health and reduce health inequalities..$^{53}$ Green spaces can also encourage social interaction, physical activity, unstructured play and contact with nature. Prevalence rates for diabetes, cancers, severe headaches and depression are purportedly lower in living environments that have significant green spaces. ${ }^{47}$

Despite much Federal Government rhetoric about a sustainable population policy, there is still little sign of one. Hence, it is imperative that more public health professionals become active advocates for a more balanced approach to sustainable population.

\section{Conclusions}

Climate change is likely to be the biggest global health threat of the $21^{\text {st }}$ century. There are many existing stressors that exacerbate climate change and, in turn, affect human health. Rapidly increasing Australia's population will make these stressors an even greater threat. While high consumption in developed countries is a major cause of climate change, current rapid rates of population growth exacerbate the problem immensely in Australia. Sadly, its impact will be greatest on the vulnerable groups. 
This paper has demonstrated that rapid population growth can have negative impacts on human health and development and the provision of essential services, and can further compromise the abilities of the vulnerable members of our communities to achieve a good quality of life.

It is now critical that Federal, State and local governments develop sustainable population plans that aim to stabilise population growth as an option. These population policies must consider that the single most effective way for Australia to reach its climate change targets and to improve public health equity, is to slow the rates of current population growth

\section{References}

1. Birrell B, Healy E. Population growth and Australia's Greenhouse Gas Emissions Commitments. People and Place. 2009;17(4):18-28.

2. O'Connor M, Lines W. Overloading Australia: How Governments and Media Dither and Deny on Population. Sydney (AUST): Envirobook; 2008.

3. Pelser D. Super size me: is a big Australia good for our health? Med J Aust [internet]. 2010 [cited 2010 Apr 12]:526-7. Available from: http://www.phaa.net.au/ documents/email/Pelser2010supersizeAusMJA.pdf

4. Henry K. To build, or not to build: infrastructure challenges in the years ahead and the role of Governments. Address to the Conference on the Economics of Infrastructure in a Globalised World: Issues, Lessons and Future Challenges; 2010 [cited 2010 Apr 21] March 18; Sydney, Australia; 2010. Available from: http://ops.fhwa.dot.gov/ publications/fhwahop08047/intl_cplessons.pdf

5. Egger G, Swinburn B, Stanley F, Phelps K. An open letter to politicians on climate change and obesity. Med J Aust. 2010:192(6):359-60

6. Benson S. Australia's population set to reach 42 million by 2050 , study reveals. Herald Sun. 2010 April 17. p. 21

7. Carson R. Silent Spring. New York (NY): Houghton Mifflin; 1962

8. Howat $\mathrm{P}$, Ritchie J. Sustainable population - implications for health promotion. Health Promot J Austr. 2004;15(2):103-8.

9. Department of Sustainability, Environment, Water, Population and Communities. A Sustainable Population Strategy for Australia - Issues Paper. Canberra (AUST): Commonwealth of Australia; 2010.

10. Brownson RC, Royer C, Ewing R, McBride TD. Researchers and policymakers: travellers in parallel universes. Am J Prev Med. 2006;30(2):164-72

11. Kelly MP, Speller V, Meyrick J. Getting Evidence into Practice in Public Health. London (UK): National Institute for Health and Clinical Excellence; 2004 [cited 2011 Jun 15]. Available from: http://www.nice.org.uk/download.aspx?o=508124

12. Stephenson J. Population dynamics and climate change: what are the links? Journal of Public Health. 2010; 32(2):150-6.

13. Bloom DE, Williamson JG. Demographic transitions and economic miracles in emerging Asia. World Bank Economic Review. 1998;12:419-55.

14. Department of Climate Change. White Paper on Carbon Pollution Reduction Scheme (CPRS). Vol 1. Canberra (AUST): Commonwealth of Australia; 2008.

15. Department Climate Change. Tracking to the Kyoto Target 2007: Australia's Greenhouse Emissions Trends 1990 to 2008-2012 and 2020. Canberra (AUST): Commonwealth of Australia; 2008

16. Pachauri RK, Reisinger A. Climate Change 2007 - Synthesis Report. Geneva (CHE): Intergovernmental Panel on Climate Change (IPCC); 2007. p. 104

17. Garnuat R. The Garnuat Climate Change Review. Melbourne (AUST): Cambridge University Press; 2008

18. Murtaugh PA, Schlax MG. Reproduction and the carbon legacies of individuals. Global Environmental Change. 2009;19:14-20.

19. Sustainable Population Australia. Population Policy [Internet]. Canberra (AUST): SPA 2008 [cited 2010 Apr 26]. Available from: http://www.population.org.au/

20. Smith JB, Schneider SH, Oppenheimer M, Yone GW, et al. Assessing dangerous climate change through an update of the intergovernmental Panel on Climate Change (IPCC) "reasons for concern". Proc Nat Acad Sci U S A. 2009;106:4133-7.

21. McAlpine CA, Syktus Jl, Deo RC, McGowan HA, et al. modelling the impact of historical land cover change on Australia's regional climate. Geophysical Research Letters. 2007;34:L22711.1-L22711.6.

22. McNally R, Bennet AF, Thomson JR, Redford JQ, et al. Collapse of avifauna: climate change appears to exacerbate habitat loss and degradation. Diversity and Distributions. 2009;15:720-30.

23. Commonwealth, Parliamentary Debates, House of Representatives, 20 October 2010, 956-974 (Thomson K).

24. Parry M, Lowe J, Hanson C. Overshoot, adapt and recover. Nature. 2009;458:1 102-3.

25. Orr D. Baggage: the case for climate mitigation. Conserv Biol. 2009;23:790-3.

26. Pittock A. Climate Change. The Science, Impacts and Solutions. Melbourne (AUST): CSIRO Publishing; 2009
27. Lindenmayer D, Olson MH, Morton S, Dover S. Ten Commitments: Reshaping the Lucky Country's Environment. Melbourne (AUST): CSIRO Publishing; 2008. p. 113-118.

28. Department of the Environment and Heritage. Australian State of the Environment 2006. Canberra (AUST): Commonwealth of Australia; 2006.

29. Productivity Commission. Waste Management, Report No. 38. Canberra (AUST): Commonwealth of Australia; 2006. p. 20.

30. Department Infrastructure and Transport. Health Impacts of Transport Emissions in Australia: Economic Costs. Canberra (AUST): Commonwealth of Australia; 2005

31. Australian Bureau of Statistics. 1370.0 - Measures of Australia's Progress. Canberra (AUST): ABS; 2010

32. O'Sullivan J. The downward spiral of hasty population growth. On Line Opinion [internet]. 2010 March 8 [cited 2011 Jun 20]. Available from: http://www. onlineopinion.com.au/view.asp?article $=10137$

33. Stanley J, Loader C. Road Transport and Climate Change: Stepping off the Greenhouse Gas [Report]. Melbourne (AUST): Bus Association of Victoria; 2008

34. Department Infrastructure and Transport. State of Australian Cities, 2010. Canberra (AUST): Commonwealth of Australia; 2010

35. Department of the Environment and Heritage. Second National In-service Emissions Study (NISE2) - Light Duty Petrol Vehicle Emissions Testing. Canberra (AUST): Commonwealth of Australia; 2009.

36. Hinwood AL, Rodriquez C, Runnion T, Farrar D, Murray F, Horton A, et al. Risk factors for increased BTEX exposure in four Australian cities. Chemosphere. 2007;66:533-451.

37. Rodriquez C, Tonkin R, Horwitz P, Heyworth J, Kusel M, de Klerk N, et al. The relationship between outdoor air quality and respiratory symptoms in young children. Int J Environ Health Res. 2007;17(5):351-60.

38. Department of Sustainability, Environment, Water, Population and Communities. A Sustainable Population Strategy for Australia - Issues Paper. Canberra (AUST): Commonwealth of Australia; 2010

39. National Housing Supply Council. State of Supply Report, 2008. Canberra (AUST): Commonwealth of Australia; 2009.

40. Emerson D. Income cheats keep State homes. The West Australian. 2010 October 1 Oct:11.

41. Marmot Review. Fair Society, Healthy Lives (The Marmot Review). London (UK): Department for Epidemiology \& Public Health, University College London; 2010

42. Howden-Chapman P, Pierse N, Nicholls S, et al. Effects of improved home heating on asthma in community dwelling children: Randomised controlled trial. BMJ. 2008;337:a1411.

43. Bennett KM. Low level social engagement as a precursor of mortality among people in later life. Age Ageing. 2002;31:165-8.

44. Hamilton C, Mail E. Downshifting in Australia: A Sea-change in the Pursuit of Happiness. Discussion Paper No.50. Canberra (AUST): The Australia Institute; 2003.

45. Van Os, Kapur S. Schizophrenia. Lancet. 2009;374:635-45.

46. Brookfield P. The provision of open space for urban residents: theory of the relationship between community environmental values and performance based planning processes. Proceedings of the State of Australian Cities Conference; 2007 November 27-30; Adelaide, South Australia. Australia, University New South Wales; 2007 [cited 2011 Jan 12]. Available from: http://www.fbe.unsw.edu.au/cityfutures/ SOAC/theprovisionofopenspace.pdf

47. Maas J,Verheij RA, de Vries S, et al. Morbidity is related to a green living environment. J Epidemiol Community Health. 2009;63:967-73.

48. The Treasury. The Intergenerational Report 2010. Canberra (AUST): Commonwealth of Australia; 2010.

49. Australian Bureau of Statistics. 3101.0 - Australian Demographic Statistics. Canberra (AUST): ABS; 2009

50. Australian Medical Association. AMA Public Hospital Report Card 2009: An AMA Analysis of Australia's Public Hospital System. Canberra (AUST): AMA; 2009.

51. Hugo G. Australia's future population growth: An important issue for all Australians. Issues. 2010;91:12-16.

52. Marmot M, Allen J, Goldblatt P. A social movement, based on evidence, to reduce inequalities in health. Soc Sci Med. 2010;71:1254-8.

53. Mitchell R, Popham F. Effect of exposure to natural environment on health inequalities: an observational population study. Lancet. 2008;372(9650):1655-60.

\section{Authors}

Peter Howat, Centre for Behavioural Research in Cancer Control, Curtin University.

Melissa Stoneham, Public Health Advocacy Institute of Western Australia, Curtin University

\section{Correspondence}

Professor Peter Howat, Curtin Health Innovation Research Institute (CHIRI), GPO Box U1987, Perth, WA 6845;

e-mail:p.howat@curtin.edu.au 